\title{
ANALISIS PENERAPAN CAT AIR DARI BAHAN MAKANAN TERHADAP KARYA LUKIS MAHASISWA SENI RUPA UNIPA SURABAYA
}

\author{
Sepbianti Rangga Patriani \\ Pendidikan Seni Rupa Universitas PGRI Adi Buana Surabaya \\ nirangga@gmail.com \\ Herlina \\ Pendidikan Seni Rupa Universitas PGRI Adi Buana Surabaya \\ rinhinkari12@gmail.com
}

\begin{abstract}
Abstrak
Penciptaan karya seni tidak terpaku pada media tertentu saja. Dalam bidang kesenirupaan media merupakan wujud ekspresi. Setiap media memiliki karakter dan kekhasan masing-masing. Seperti halnya cat air yang diterapkan pada permukaan kertas. Akan tetapi, tidak dipungkiri bahwa penggunaan media-media cat berkualitas baik dalam berkarya membutuhkan biaya yang tidak sedikit. Cat air yang dibuat dari bahan makanan diharapkan dapat menjadi solusi terhadap fenomena keterbatasan media berkualitas dengan pertimbangan ekonomi, sehingga mahasiswa dapat berkarya dengan media yang lebih kreatif. Tujuan dari penelitian ini adalah untuk mengetahui penerapan cat air dari bahan makanan terhadap karya lukis mahasiswa. Penelitian ini menggunakan pendekatan deskriptif kualitatif, melalui tahapan proses pembuatan cat air dan proses berkarya. Teknik pengumpulan informasi dilakukan dengan cara observasi terhadap proses pembuatan cat air dari bahan makanan, dan proses berkarya mahasiswa seni rupa pada mata kuliah praktek. Selain itu juga dilakukan pendokumentasian berupa pengambilan gambar selama pelaksaan penelitian dan pengumpulan hasil karya mahasiswa untuk diamati lebih lanjut. Hasil analisis warna cat air dari bahan makanan dapat disimpulkan bahwa pada dasarnya cat air yang dihasilkan memiliki kualitas yang cukup baik. Hal ini ditandai dari tekstur cat air yang dihasilkan kental tanpa gumpalan serta warna yang dihasilkan cerah dan bersih (jelas). Adapun dari tampilan visual yang diterapkan pada kertas gambar menunjukkan bahwa intensitas warna cat air dari bahan makanan menghasilkan tampilan warna yang lembut (soft), sedangkan intensitas cat air buatan pabrik menghasilkan tampilan warna yang lebih kuat dibanding cat air dari bahan makanan.
\end{abstract}

Kata Kunci : cat air, bahan makanan

\section{PENDAHULUAN}

Penciptaan karya seni tidak terpaku pada media tertentu saja. Bidang-bidang kesenirupaan menggunakan berbagai macam media sebagai wujud ekspresi. Setiap media memiliki karakter dan kekhasan masingmasing. Kekhasan tiap media warna yang 
digunakan juga menentukan teknik yang digunakan. Seperti cat minyak yang disapukan di atas kanvas, atau pastel yang digoreskan di atas kertas. Oleh sebab itu kegiatan-kegiatan perkuliahan program studi seni rupa wajib mengenal dan memahami karakteristik serta teknik dari media yang akan digunakan ketika berkarya.

Tentunya untuk menghasilkan karya seni rupa dengan tampilan visual yang menarik membutuhkan bahanbahan yang berkualitas. Semakin berkualitas cat yang digunakan maka semakin cemerlang warna yang dihasilkan. Dan semakin cemerlang warna yang digunakan, maka akan semaki menunjang kualitas karya yang dihasilkan.

Gambaran ideal yang diharapkan bahwa karya yang dihasilkan oleh mahasiswa seni rupa tentunya berkualitas. Namun hal ini dapat menjadi suatu kendala ketika diperhadapkan pada situasi ekonomi. Tidak dipungkiri bahwa penggunaan media-media cat berkualitas baik dalam berkarya membutuhkan biaya yang tidak sedikit. Terlebih dengan sejumlah mata kuliah praktek yang membutuhkan alat dan media berkarya yang harus disesuaikan dengan bidang penerapannya. Jika dengan pertimbangan bahwa setiap karya menggunakan media berkualitas baik, maka dapat diperkirakan seberapa banyak dana yang mesti dikeluarkan untuk menunjang sejumlah mata kuliah tersebut.

Cat air merupakan salah satu media pewarna yang umum digunakan dalam kegiatan perkuliahan praktek di jurusan Seni Rupa. Jika dibandingkan dengan cat lain, cenderung lebih praktis dan dapat digunakan pada sejumlah mata kuliah praktek dua dimensi. Cat air yang beredar di pasaran memiliki sejumlah pilihan kualitas dan harga. Kondisi yang diharapkan tentunya mahasiswa dapat berkarya dengan media yang berkualitas, namun pada kenyataannya mereka akan memilih barang dengan pertimbangan kebutuhan dan dana yang dimiliki. Sehingga terkadang berakhir pada pemilihan media dengan harga murah berkualitas standar atau lebih buruknya di bawah standar. Hal ini tentunya memengaruhi kualitas hasil karya lukis yang dihasilkan, sementara penilaian terhadap sebuah karya didasarkan pada tampilan visualnya.

Cat air yang dibuat dari bahan makanan diharapkan dapat menjadi solusi terhadap fenomena keterbatasan media berkualitas dengan pertimbangan ekonomi. Sebagaimana yang diketahui bahwa kreatif tidak hanya sebatas ide dan proses berkarya, namun juga pada medianya. Selain itu, diharapkan dengan penggunaan cat air dari bahan makanan dapat menjadi sumber pengetahuan baru bagi mahasiswa yang nantinya akan diterapkan pada bidang lain. Dan hal tersebut diperjelas oleh Bastomi (1992: 102) bahwa mencipta dapat diperoleh dari bahan-bahan dari dunia sekeliling senimannya. Melalui fenomena tersebut dapat dikaji lebih lanjut terkait penerapan cat air dari bahan makanan terhadap karya lukisan mahasiswa seni rupa.

\section{KAJIAN PUSTAKA}

\section{Teori Warna}

Dalam kehidupan sehari-hari warna memiliki peranan yang sangat 
penting. Salah satunya dalam kehidupan berkesenian, bagi seniman warna merupakan daya tarik untuk menciptakan kesan hidup pada karya seni rupa. Secara umum, dapat dideskripsikan bahwa warna adalah kesan yang ditimbulkan oleh cahaya pada mata. Menurut Ilmu Bahan, warna adalah semacam zat berupa pigmen (pigment) yang berarti zat warna ( Azis Said, 2006: 35). Sehubungan dengan itu, warna memiliki tiga dimensi dasar yaitu hue, nilai (value), dan intensitas (intensity). Hue adalah gelombang khusus dalam spektrum dan warna tertentu. Misalnya spektrum warna merah disebut hue merah. Nilai (value) adalah nuansa yang terdapat pada warna, seperti nuansa cerah atau gelap, sedangkan intensitas adalah kemurnian dari hue warna.

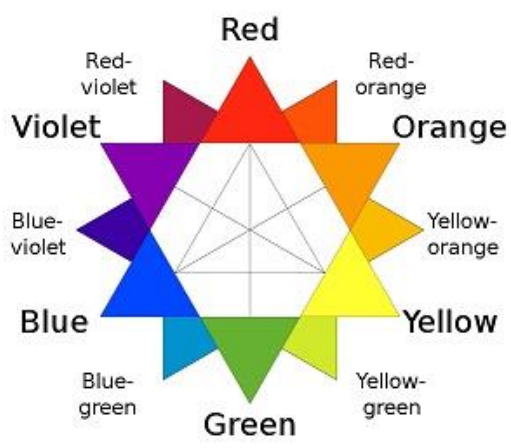

Gambar 1. Model Lingkaran Warna Brewster

\section{Tinjauan Tentang Cat Air}

Cat air merupakan suatu cara mewarnai yang melibatkan proses melarutkan warna dalam air. Cat air atau aquarel memiliki sifat transparan yang dapat menghasilkan kesan ekspresif maupun impresif pada suatu karya seni rupa. Menurut Crawshaw, cat air adalah medium yang sangat populer. Sehingga, melalui medium cat air dapat menggambar berbagai macam benda. Peralatan dalam menggambar dengan cat air juga tidak begitu rumit. Seperti halnya, ketika melukis di alam terbuka dengan menggunakan media cat air, perangkat yang dibutuhkan hanya pensil, cat air, kuas, palet, kertas, dan air (Alwyn Crawshaw, 2006:6).

Menurut Scoot, dalam menciptakan karya seni rupa dengan media cat air terdapat beberapa teknik dasar (Eric M. Scott, 2013) antara lain;

1. Teknik kering (wet-on-dry) yaitu teknik cat air dengan cara menuangkan kuas yang telah dibasahi pada kertas kering.

Gambar 2. Efek teknik kering

2. Teknik basah (wet-on-wet) yaitu teknik cat air dengan cara menuangkan kuas basah pada kertas basah.

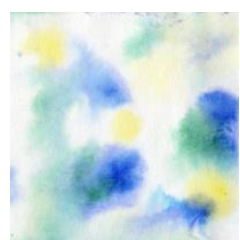

Gambar 3. Efek Teknik basah

3. Teknik celup atau teknik angkat yaitu teknik cat air dengan cara mencelupkan media kertas ataupun media plastik ke dalam cat air yang telah diolah warnanya kemudian diangkat. Teknik ini dapat menghasilkan efek warna cat air yang bervariasi.
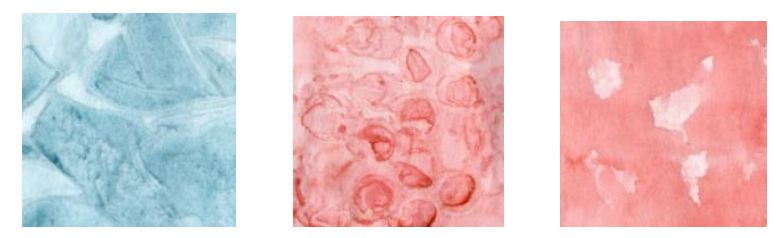
4. Teknik Sponge yaitu teknik cat air dengan cara menempelkan bahan sponge/ spon pada kertas.

Gambar 5. Efek Teknik Sponge

5. Teknik Stamp/ cap yaitu teknik cat air dengan cara membuat cap gambar objek seperti lingkaran gelembung yang telah diwarna kemudian dituangkan pada kertas.

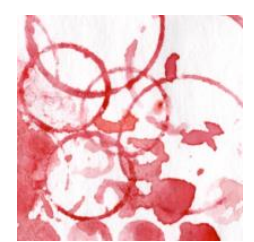

Gambar 6. Efek Teknik Cap

6. Teknik Salt yaitu teknik cat air dengan cara menggunakan bahan garam sebagai media campuran. Teknik ini dilakukan dengan cara menaburkan bahan garam ke dalam cat air pada bidang kertas kemudian dipoles dengan kuas.

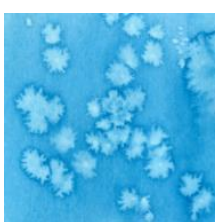

Gambar 7. Efek Teknik Salt

7. Teknik Stipple yaitu teknik cat air dengan cara memercikkan warna cat air pada bidang kertas dengan menggunakan alat penggosok gigi/ sikat gigi dan jari

\section{Gambar 8. Efek Teknik Stipple}

\section{Bahan Makanan Sebagai Media Pewarna}

Secara umum, makanan adalah bahan yang berasal dari sumber hewani dan tumbuhan (nabati) untuk dikonsumsi oleh mahluk hidup sebagai nutrisi dan tambahan tenaga/ energi. Selain itu, makanan juga dapat membantu pertumbuhan badan dan otak bagi manusia. Oleh karena, dalam makanan terdapat kandungan gizi seperti protein, lemak, dan karbohidrat yang mempunyai fungsi berbeda. Protein berfungsi untuk membantu pertumbuhan tubuh. Lemak berfungsi saat tubuh kekurangan karbohidrat, dan memecah menjadi glukosa yang digunakan bagi tubuh saat membutuhkan energi. Adapun karbohidrat merupakan jenis gizi yang utama karena sebagai sumber energi/ tenaga sehari-hari. Sehubungan dengan itu, makanan yang dikonsumsi oleh mahluk hidup memiliki fungsi untuk menghasilkan energi dalam kelangsungan aktifitas, mengganti sel-sel tubuh yang telah usang atau rusak, pertumbuhan tubuh, dan sebagai zat pelindung dalam tubuh.

Beralih dari fungsi bahan makanan yang keutamaannya sebagai sumber energi dan gizi. Akan tetapi, dalam penelitian ini bahan makanan tersebut dipergunakan sebagai media dalam menghasilkan sebuah karya seni rupa. Bahan makanan yang digunakan sebagai media berkarya adalah bahan tambahan makan (BTM) yang terdapat dalam 
golongan Pemutih dan pematang tepung (flour treatment Agent), Pengawet (Preservative), dan Pengatur keasaman (acidity regulator). Bahan Tambahan Makanan ini bisa merupakan bahanbahan tambahan, seperti vitamin atau asam-asam amino esensial, bahan pewarna makanan, bahan yang memberikan rasa tertentu dan juga bahan-bahan pengawet.

Dalam meciptakan suatu karya seni rupa, seorang seniman tidak terikat oleh penggunaan media maupun bahan untuk berkarya. Seperti halnya, bahan makanan yang dijadikan sebagai media dalam menciptakan suatu karya seni rupa. Adapun salah satu bahan makanan tersebut terdapat pada golongan pewarna makanan yang dapat diolah menjadi media pewarna dengan cara mencampur beberapa bahan makanan untuk menjaga ketahanan warnanya. Bahan pewarna makanan tersebut dapat dijadikan sebagai salah satu media dalam teknik penerapan cat air.

Penelitian ini menggunakan pendekatan deskriptif kualitatif. Pelaksanaan penelitian melalui 3 tahapan yang meliputi tahap 1 yakni proses pembuatan cat air, tahap 2 proses berkarya, dan tahap 3 analisis hasil karya.

\section{PEMBAHASAN}

\section{Tahap I (Proses Pembuatan Cat Air)}

Tahap ini merupakan kegiatan yang merujuk pada proses persiapan alat dan bahan, pengolahan bahan, dan analisis terhadap cat air dari bahan makanan. Alat dan bahan dalam penelitian merujuk pada item yang digunakan dalam proses pembuatan cat air. Alat dan bahan pembuatan cat air ini merupakan bahan-bahan yang umumnya digunakan sebagai bahan untuk membuat kue. Sehingga pada prosesnya, penggunaan alat dan bahan tidaklah membutuhkan keahlian khusus serta aman dalam penggunaannya.

Bahan utama pembuatan cat air yaitu Soda kue/ baking soda, Cuka putih (white vinegar), Tepung maizena (corn starch), Sirup jagung (corn syrup), dan Pewarna makanan. Adapun alat yang digunakan adalah wadah plastik, sendok ukuran besar dan kecil, pengaduk adonan (whisk), spatula, gelas ukur, timbangan, mangkuk plastik, stik permen, dan cetakan es.

Selain alat dan bahan di atas, terdapat beberapa item benda yang dibutuhkan pada untuk uji coba warna. Bahan tersebut antara lain kertas cat air (watercolor paper), garam, tisu, cat air buatan pabrik, spons, sikat gigi, tutup botol bekas, kuas, dan selotip kertas (masking tape). Alat dan bahan ini digunakan untuk mengetahui kualitas warna sebelum digunakan pada tahap penerapan cat air.

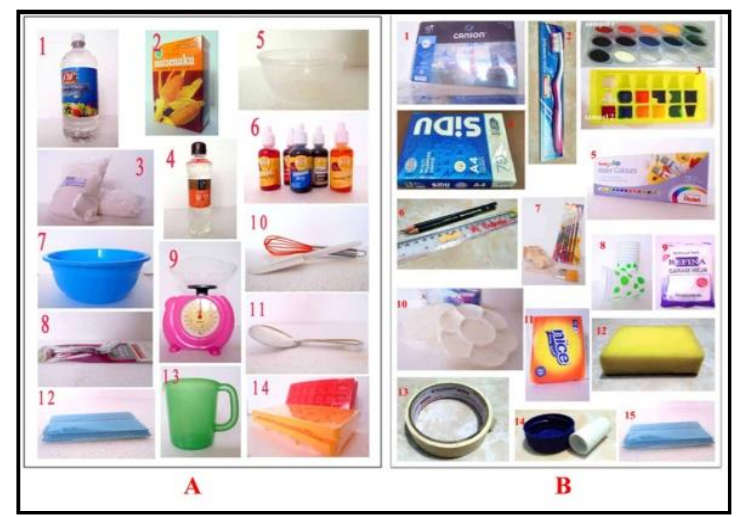

Gambar 9. Alat dan bahan yang digunakan dalam proses pembuatan cat air (A) dan alat dan bahan yang dibutuhkan untuk uji coba warna (B) 
Setelah alat dan bahan yang dibutuhkan siap, maka dilanjutkan pada proses pengolahan bahan yang dilakukan melalui tahap uji coba. Uji coba ini dilaksanakan dengan melakukan pengamatan dan analisis terhadap tekstur, kecerahan dan kepekatan warna.

Pada tahap percobaan menggunakan takaran yang lebih kecil dengan menggunakan gelas cup berdasarkan sumber situs web. Perbandingan bahan soda kue, tepung maizena, dan cuka putih adalah $1: 1: 3 / 4$. Sedangkan untuk sirup jagung dan pewarna kue ditambahkan dalam jumlah yang kecil yakni 2-3 sendok makan untuk sirup jagung dan 3-5 tetes untuk pewarna kue. Bahan yang telah siap kemudian diolah dengan menempatkan soda kue pada wadah. Selanjutnya cuka putih dituang ke dalam wadah berisi soda kue sedikit demi sedikit. Hal ini bertujuan agar bahan tidak meluap ketika kedua bahan dicampurkan. Ketika soda kue dan cuka putih dicampurkan akan memunculkan reaksi gelembung (busa).

Jika kedua bahan telah tercampur dengan baik. Selanjutnya 2-3 sendok makan sirup jagung dimasukkan kedalam campuran bahan tadi sambil diaduk. Kemudian tambahkan tepung maizena sedikit demi sedikit agar bahan tidak menggumpal. Hasil akhir dari campuran bahan tersebut berbentuk kental. Tahap selanjutnya adonan dituang pada cetakan es sejumlah 12 ruang pada cetakan es. Pada masingmasing ruang diberi pewarna makanan 2-3 tetes. Setelah pewarna tercampur dengan rata maka cat air sudah dapat langsung digunakan. Cat air akan menjadi padat setelah 1-2 hari. Cat air dapat diencerkan dengan menggunakan cuka. Hasil analisis terhadap warna cat air melalui tahap uji coba adalah sebagai berikut.

\section{Hasil analisis terhadap warna cat air}

\begin{tabular}{|l|l|}
\hline $\begin{array}{c}\text { Komponen } \\
\text { Yang } \\
\text { diamati }\end{array}$ & \multicolumn{1}{|c|}{ Hasil pengamatan } \\
\hline $\begin{array}{l}\text { Tekstur cat } \\
\text { air }\end{array}$ & $\begin{array}{l}\text { Tekstur yang dihasilkan kental tanpa } \\
\text { gumpalan }\end{array}$ \\
\hline $\begin{array}{l}\text { Kecerahan } \\
\text { warna }\end{array}$ & $\begin{array}{l}\text { Warna yang dihasilkan cerah dan } \\
\text { bersih }\end{array}$ \\
\hline $\begin{array}{l}\text { Kepekatan } \\
\text { warna }\end{array}$ & $\begin{array}{l}\text { Warna yang dihasilkan kurang pekat } \\
\text { sehingga ketika diaplikasikan pada } \\
\text { kertas menghasilkan warna yang } \\
\text { sedikit pudar }\end{array}$ \\
\hline
\end{tabular}

Tabel di atas menunjukkan bahwa cat air yang dihasilkan pada tahap percobaan menghasilkan kualitas yang cukup baik. Hal ini ditandai dari tekstur cat air yang dihasilkan kental tanpa gumpalan serta warna yang dihasilkan cerah dan bersih (jelas).

Tahap uji coba kedua terkait proses pembuatan cat air merujuk pada komposisi yang telah diadaptasi pada tahap percobaan dengan menggunakan takaran yang lebih besar (sampel 2). Bahan bubuk diukur dalam jumlah gram menggunakan timbangan, sedangkan bahan cair diukur dalam jumlah milliliter menggunakan gelas ukur. Proses pembuatan cat air dilaksanakan sesuai dengan urutan cara kerja pada tahap percobaan. Perbedaannya hanya terletak pada banyaknya jumlah takaran bahan dan pewarna makanan. Komposisi bahan yang digunakan adalah \pm 1.600 gr untuk baking soda dan tepung maizena, \pm 2100 $\mathrm{ml}$ cuka putih, dan $\pm 250 \mathrm{ml}$ sirup jagung. Sedangkan bahan pewarna ditambahkan pada adonan yang telah dituang pada cetakan es sebanyak \pm 10 tetes untuk tiap warna. 


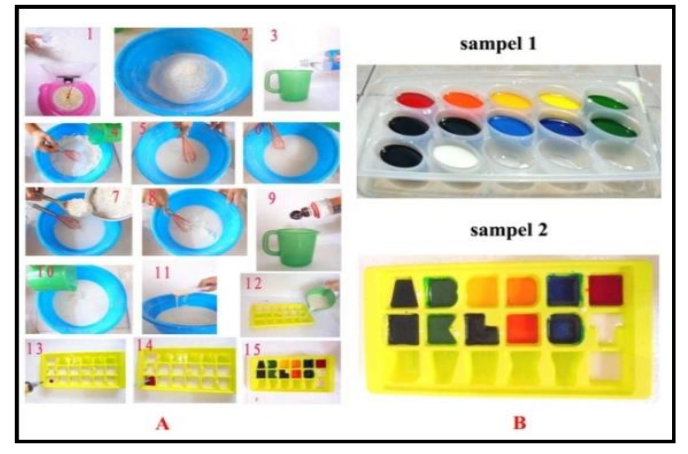

Gambar 10. Proses pembuatan adonan cat air (A) dan sampel warna yang akan digunakan pada tahap uji coba

Gambar tersebut menunjukkan bahwa hasil perbandingan menunjukkan perbedaan warna yang jelas. Secara visual penggunaan cat air sampel 2 menghasilkan warna yang lebih pekat dibandingkan dengan sampel 1. Jadi dapat disimpulkan bahwa warna sampel 2 memiliki kualitas yang lebih baik dari sampel 1 .

Uji coba warna selanjutnya yakni dengan membandingkan cat air sampel 2 dengan cat air buatan pabrik. Hal ini bertujuan untuk memperoleh gambaran tentang kualitas cat air dari bahan makanan jika dibandingkan dengan cat air buatan pabrik. Uji coba ini dilakukan melalui kegiatan perbandingan tampilan visual dari segi intensitas warna dan teknik cat air.

jika ditinjau dari segi intensitas warna, kualitas warna cat air dari bahan makanan memiliki kualitas yang hampir sama dengan cat air buatan pabrik. Intensitas warna yang dihasilkan menunjukkan tingkat kecemerlangan yang sama, beberapa warna menunjukkan warna cenderung lebih pudar. Adapun pewarna bahan makanan yang dijadikan sebagai uji coba yakni merah cabe, ungu, coklat kopi, kuning muda, kuning tua, hijau muda, biru dan blue sky.
Jika ditinjau dari penerapan teknik cat air, uji coba kualitas warna memiliki kualitas yang hampir sama dengan cat air buatan pabrik. Meski demikian ada beberapa diantara teknik yang digunakan menghasilkan tampilan yang berbeda yakni teknik menggunakan garam dan teknik percikan. Sedangkan penerapan teknik celup dengan menggunakan cat air dari bahan makanan tidak menampakkan hasil yang baik sebagaimana jika menggunakan cat air buatan pabrik.

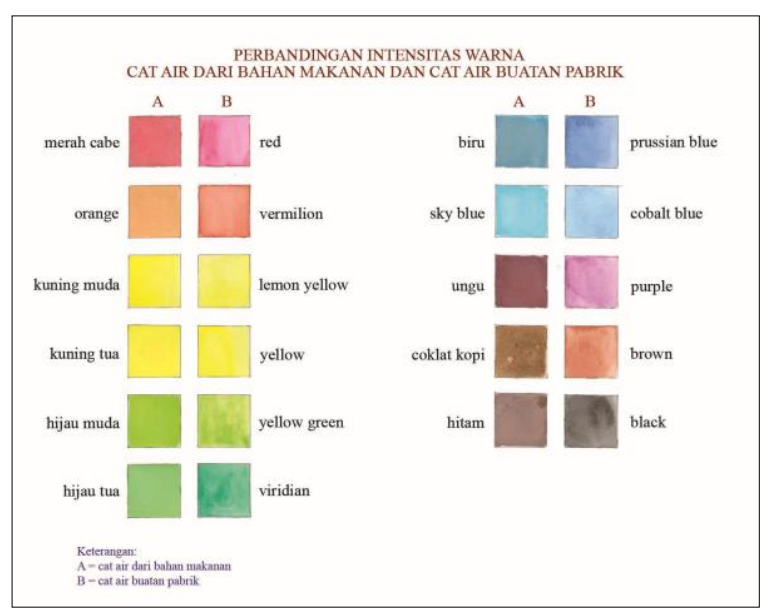

Gambar 11. Perbandingan intensitas warna cat air dari bahan makanan dan cat air buatan pabrik

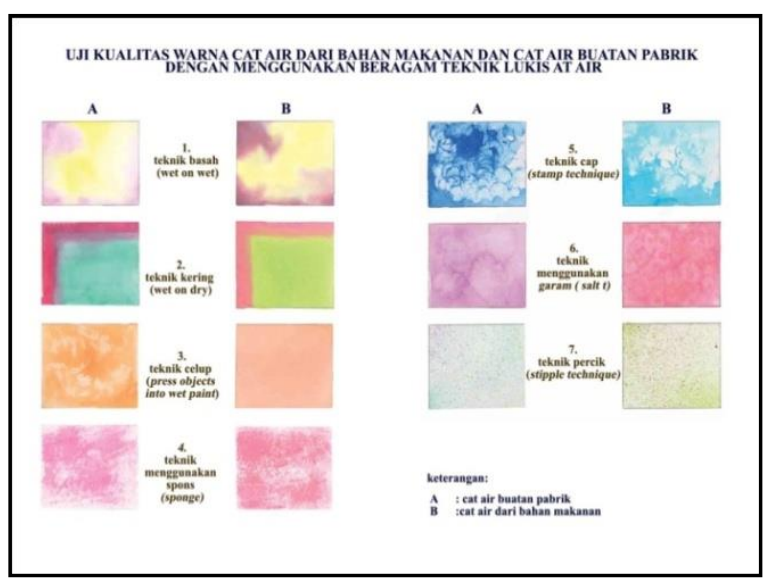

Gambar 12. Perbandingan kualitas warna cat air dari bahan makanan dengan cat air buatan pabrik menggunakan beragam teknik lukis cat air 
2. Tahap II (proses berkarya lukis menggunakan cat air dari bahan makanan)

Tahap ini merupakan kegiatan yang dilakukan dengan melibatkan subjek penelitian yakni 30 mahasiswa pendidikan seni rupa Unipa Surabaya yang dihimpun dari beberapa kelas, baik yang sudah dan belum menempuh mata kuliah lukis. Hal ini bertujuan agar karya yang dihasilkan lebih objektif. Tahap ini dilaksanakan melalui tahap persiapan alat dan media lukis, sketsa gambar berdasarkan tema, dan penerapan cat air dari bahan makanan.

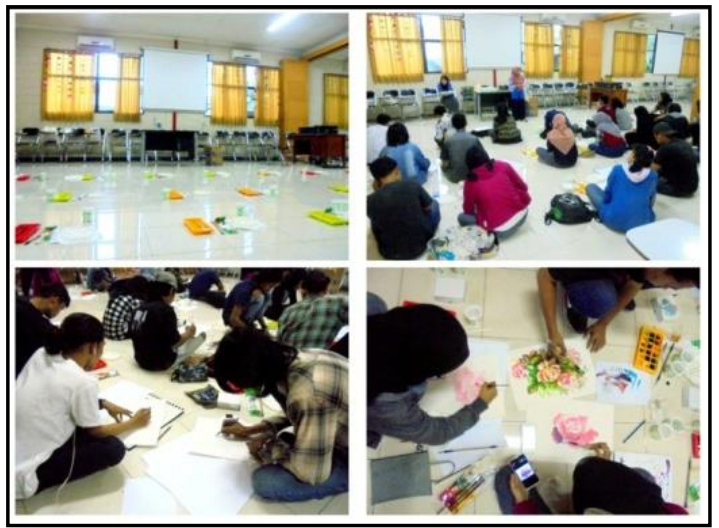

Gambar 13. Proses berkarya lukis menggunakan cat air dari bahan pewarna makanan

Persiapan alat dan media lukis yang digunakan dalam proses berkarya lukis merupakan alat dan bahan yang sudah umum digunakan dalam melukis cat air antara lain pensil, penghapus, kuas lukis berbagai ukuran, palet cat air (watercolor palette), kertas HVS, kertas cat air (watercolor paper), tisu, cuka, dan gelas plastik. Sedangkan bahan pewarna yang digunakan adalah cat air dari bahan makanan. Sebelum melaksanakan kegiatan berkarya lukis, mahasiswa diberikan pengantar serta petunjuk teknis dalam menggunakan cat air dari bahan makanan. Pengantar bertujuan untuk memberikan gambaran tentang kegiatan yang akan dilaksanakan terutama bagi mahasiswa yang belum menempuh mata kuliah lukis. Sedangkan petunjuk teknis bertujuan untuk memberikan penjelasan terkait prosedur penggunakan alat dan media.

Pada tahap pembuatan sketsa gambar ditentukan berdasarkan efisiensi waktu untuk menyelesaikan karya. Adapun pilihan tema antara lain referensi gambar dengan objek bunga, buah dan pemandangan. Mahasiswa diberi kekebasan untuk memilih salah satu diantara tema tersebut. Referensi gambar disiapkan agar memudahkan saat membuat sketsa gambar serta pemilihan warna. Selanjutnya mereka membuat sketsa gambar pada kertas cat air berdasarkan tema yang telah dipilih.

Selanjutnya, pada tahap penerapan cat air dari bahan makanan dilakukan dengan mengaplikasikan cat pada sketsa yang telah dibuat, cat harus diencerkan dengan menggunakan cuka terlebih dahulu. Pada penggunaannya cat dapat diaplikasikan langsung pada kertas untuk menghasilkan kontur dan warna yang jelas, atau dengan menambahkan sedikit air untuk menghasilkan kontur dan warna lebih tipis (transparan).

\section{SIMPULAN}

Berdasarkan hasil pengamatan dapat disimpulkan bahwa pada prinsipnya bahan makan dapat dimanfaatkan sebagai media dalam pembuatan cat air. Melalui tahap percobaan/ eksperimen proses pembuatan cat air dari bahan makanan menunjukkan bahwa pada dasarnya cat air yang dihasilkan memiliki kualitas 
yang cukup baik. Hal ini ditandai dari tekstur cat air yang dihasilkan kental tanpa gumpalan serta warna yang dihasilkan cerah dan bersih (jelas). Adapun dari tampilan visual yang diterapkan pada kertas gambar menunjukkan bahwa intensitas warna cat air dari bahan makanan tidak jauh berbeda jika dibandingkan dengan cat air buatan pabrik. Intensitas warna cat air dari bahan makanan menghasilkan tampilan warna yang lembut (soft), sedangkan intensitas cat air buatan pabrik menghasilkan tampilan warna yang lebih kuat dibanding cat air dari bahan makanan. Adapun analisis karya lukisan cat air dari bahan makanan didominasi oleh unsur warna yang dihasilkan dari efek warna cat air. Warna ini memperjelas sebuah bentuk objek lukisan memberi kesan hidup pada karya lukisan. Selain itu, penguasaan teknik yang pada karyakarya lukisan yang dihasilkan mahasiswa, intensitas warna yang dihasilkan tidak jauh berbeda.

\section{DAFTAR PUSTAKA}

Bahari, Nooryan. 2008. Kritik Seni Wacana, Apresiasi, dan Kreasi. Pustaka Pelajar. Yogyakarta.

Bastomi, Suwaji. 1992. Wawasan seni. IKIP Semarang Press: Semarang.

Berril, Philip. 1996. Panduan Melukis Dengan Cat Air oleh Philip Berril "The Flying Artist". Pakar Raya Pakarnya Pustaka. Bandung.

Murata, Michinori. 1987. Mencampur Warna. Kaisei-sha.

Minantyo, Hari. 2011. Dasar-Dasar Pengolahan Makanan. Graha Ilmu. Yogyakarta.

\section{LAMPIRAN}

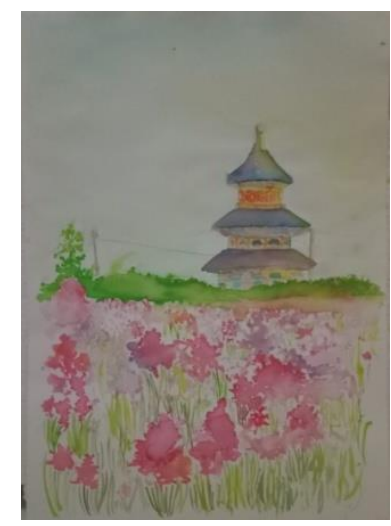

Tema Pemandangan

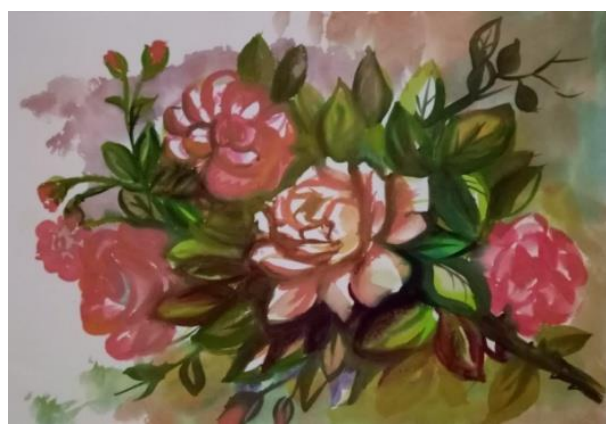

Tema Bunga

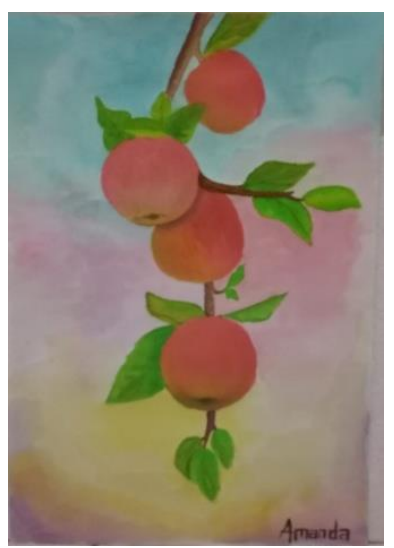

Tema Buah 